\title{
腔扁平苔癬および白板症の病変部と周辺部の病理組織学的検討
}

\author{
鉿木克年・後沢孝和・市川光大
}

茂木健司・松田 登

\section{Histopathological study between lesion and the surrounding site of oral lichen planus and leukoplakia}

\author{
Katsutoshi Suzuki - Takakazu Gozawa • Mitsuhiro Ichikawa \\ Kenji Mogi • Noboru Matsuda
}

\begin{abstract}
The lesion in 18 cases of oral lichen planus and the surrounding site about $10 \mathrm{~mm}$ from the focus, which appeared normal as seen with the eye, were examined by the direct immunofluorescent and histopathological methods. These results were compared with 13 cases of leukoplakia examined in the same way. The results were as follows.

1. For hyperkeratosis, degeneration of the basal layer of epithelium and a dense band of lymphocytes adjacent to the epithelium, which are thought to be very important in histopathologically diagnosing oral lichen planus, the incidence was $100 \%, 89 \%$ and $100 \%$, respectively, whereas the incidence of these findings at the surrounding site of the lesion was 56\%, 44\% and $78 \%$. Eleven cases $(61 \%)$ including more than 2 of the above 3 findings could be seen among the 18 cases. In the leukoplakia, the incidence of hyperkeratosis, acanthosis and inflammatory cell infiltration, which are thought to be very important for the histopathological diagnosis, was lower in the surrounding site of the lesion than in the focus.

2. In lichen planus the deposition of fibrinogen was often observed both in the focus and in the surrounding site of the lesion, and there was little difference in the localization of these sites in the complement. However, a clear difference between the focus and the surrounding site of the lesion was detected in the case of leukoplakia.

3. These results suggest that some histopathological changes have already occurred in the surrounding site of the lesion in lichen planus, and therefore medication may be preferable to surgical therapy. On the other hand, surgical therapy is considered to be a sure method in leukoplakia.
\end{abstract}

Key words: oral lichen planus (口腔扁平苦推), leukoplakia (白板症), histopathology (州理組 織兴:

\section{は じめに}

扁平苔㜣は皮虐と粘膜の慢性炎症性角化症で，Wil一 $\operatorname{son}^{1)}$ がはじめて記载して以来, 口腔病変の臨床ならび

群馬大学医学部口腔外科学教空

（主任：松田 登教授）

Department of Oral Surgery, School of Medicine, Gunma University (Chief: Prof. Noboru Matsuda) 受付日: 平成 3 年 1 月 8 日
に病理組織像については多数の報告2 13)があるが，その 成り立ちはいまだ解明されていない。

しかし，上皮固有層境界部に括㚈万紐胞性免疫機構の 異常 ${ }^{10,12)}$ ，糖尿病 ${ }^{10)}$ ，女性ホルモン ${ }^{11)}$ ，遗伝的因子 ${ }^{13)}$, 薬物 ${ }^{14)}$ が関与する報告は，本症の発症に全身的因子が保 わることを示吉资料と考兄られ，口腔内では環状酒列 した质疹の内側に発赤・びらんを生じたり，同一患者で も経過中に病変がいろいろの変化を示すことも知られて いる.

著者らは上記の事实に基づき，口腔扁平苔媬では病変 
の周辺にすでになんらかの前段階ともいらべき変化が起 こりらると推定した，そのため18症例について，病变部 と肉眼的に正常な病変の辺縁より約 $10 \mathrm{~mm}$ 離れた部位 を断端とした組織片を採取し，つぎに成書 $2,6,13,15)$ に臨 木上扁平苔寉と鑑別を要する疾患として第1にあげられ ている白板症13例について，同様に病变部とその周辺を 採取して光顕および螢光抗体法により検討し，2，3 の 知見を得たので報告する。

\section{対象と検討方法}

対象は昭和 62 年 2 月より平成 2 年 6 月末までの 3 年 5 か月間に当科を受診した口腔扁平苔鮮患者のらち, 煩, 口唇粘膜の病変 18 症例 (男性 3 例, 女性 15例), 平均年

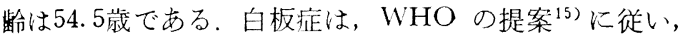
摩擦によって除去できず他の診断可能な疾患に分類でき ない白斑13例（男性 9 例，女性 4 例），平均年夦 54.0 歳 で，いずれも扁平苔淮患者と同じ期間内に来科した症例 である(表 1)。

扁平苔㶍の臨床像の基本は白色丘疹が線状に配列した 状態であり，しばしばその内側の及ならず外側にも発赤 を伴うことが知られている．粘膜の色調は赤色であるの で白色の病変は識別できるが，軽度の発赤を肉眼的に区 別することは困難といわざるを得ない，著者らは病理組

表 1 性と年粭

\begin{tabular}{|c|c|c|c|c|}
\hline \multirow{2}{*}{ 年龆 } & \multicolumn{2}{|c|}{ 扁平苔铮 } & \multicolumn{2}{|c|}{ 白板症 } \\
\hline & 男 & 女 & 男 & 女 \\
\hline $10 \sim 19$ 筬 & 0 & 0 & 1 & 0 \\
\hline $20 \sim 29$ 筬 & 0 & 0 & 0 & 0 \\
\hline $30 \sim 39$ 藏 & 0 & 1 & 0 & 0 \\
\hline $40 \sim 49$ 藏 & 0 & 3 & 1 & 1 \\
\hline $50 \sim 59$ 藏 & 1 & 9 & 3 & 3 \\
\hline $60 \sim 69$ 践 & 1 & 1 & 3 & 0 \\
\hline $70 \sim 79$ 啙 & 1 & 1 & 0 & 0 \\
\hline $80 \sim 89$ 藏 & 0 & 0 & 1 & 0 \\
\hline 合 計 & 3 & 15 & 9 & 4 \\
\hline
\end{tabular}

織片採取にあたり，前述の頓，口厚粘膜面に扣いて，丘 疹の白色調が明暸で線状をなし，その白色兵疹部の辺縁 より外側の正中方向で肉眼的に発赤, びらんがなく, 正 常と判断された約 $10 \mathrm{~mm}$ 離れた部位を断端として,さ らに正中に向い 3 4 mm の組織片を採取した（粘膜面 に長さ $10 \mathrm{~mm}$ の方眼紙を密着させて测定した。病变と 約 $10 \mathrm{~mm}$ 離れた部位を一塊として採取した症例もあ る).このよらな方法による約 $10 \mathrm{~mm}$ 離れた部位は, 肉 眼的な軽度の発赤との識別のむずかしさを考慮に入れて も，正常と判定してまず間違いはないと思われる。病变 部の採取片を2 分し，さらに病変より睢れた部位では断 端部を含め 2 分した。 2 分した切片の 1 個を $10 \%$ 中性緩 衝ホルマリンで固定後ハラフィン包埋し, $3 \mu \mathrm{m}$ の薄切 切片を作製し，脱ハラフィン後へマトキシリン・エオシ ン染色（H-E 染色）を施した。白板症の病变についても 同様に，病変部抢よび辺縁より約 $10 \mathrm{~mm}$ 離れた部位を 採取し, 組織学的観察の資料とした。䖝光抗体直接法に よる観察は, 組織片の残り半分を OCT-compound(LabTek 社) に包埋し, $-80^{\circ} \mathrm{C}$ のクリオスタット内で 4 $6 \mu \mathrm{m}$ の凍結切片を作製した。切片を乾燥後，1/15 M, pH 7.2 の燐酸緩衝液 (以下 PBS) で洗浄した後, FITC 標識抗体液を滴下し， $37^{\circ} \mathrm{C}$ の moist chamber 内で 30 分間 incubate した。 その後PBS で洗浄し, 螢光顕微 鏡 (Nikon SUR-F 型) で観察した。使用した抗体は FITC 標識ヒト IgA, IgG, IgM, C 3c, C3d, C4, C5, fibrinogen ウサギIIII清 (DAKO 社) でそれぞれ20倍 に稀釈して用いた。

\section{結果}

\section{1. 病理組織像の成績（表 2)}

扁平苔猚の病理組織像の特徽としてあけられてい $z^{13,16)}$ a）角化元進，ｂ）顆粒層の肥厚，c）梀緗胞 症, d ) 基底細胞層の障呈（基底紐胞層に拁ける水症変 性，基底細胞層の破䘫など），e）上皮直下の带状細胞 浸潤（主上してリンハ球よりなる）壳調べた。

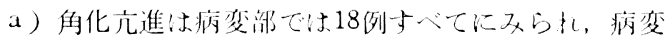
上り䄪 $10 \mathrm{~mm}$ 䕌九た部位（以下周辺洲と略与）ではや や少なく，18例中10例（56\%）に認めら机た。b）顆粒

表 2 病理組織像の成緽

\begin{tabular}{|c|c|c|c|c|c|c|c|}
\hline 病 & 名 & 例数 & 角化元進 & 顆粒層肥厚 & 棘細胞症 & 基低細胞廨障害 & 細胞浸潤 \\
\hline \multirow{2}{*}{ 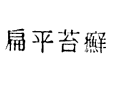 } & 病変部 & 18 & $18(100 \%)$ & $2(11 \%)$ & $4(22 \%)$ & $16(89 \%)$ & $18(100 \%)$ \\
\hline & 周辺部 & 18 & $10(56 \%)$ & 0 & $1(6 \%)$ & $8(44 \%)$ & $14(78 \%)$ \\
\hline \multirow{2}{*}{ 白 板 症 } & 病変部 & 13 & $13(100 \%)$ & & $12(92 \%)$ & $1(8 \%)$ & $8(62 \%)$ \\
\hline & 周辺部 & 13 & $7(54 \%)$ & & $1(8 \%)$ & 0 & $4(31 \%)$ \\
\hline
\end{tabular}




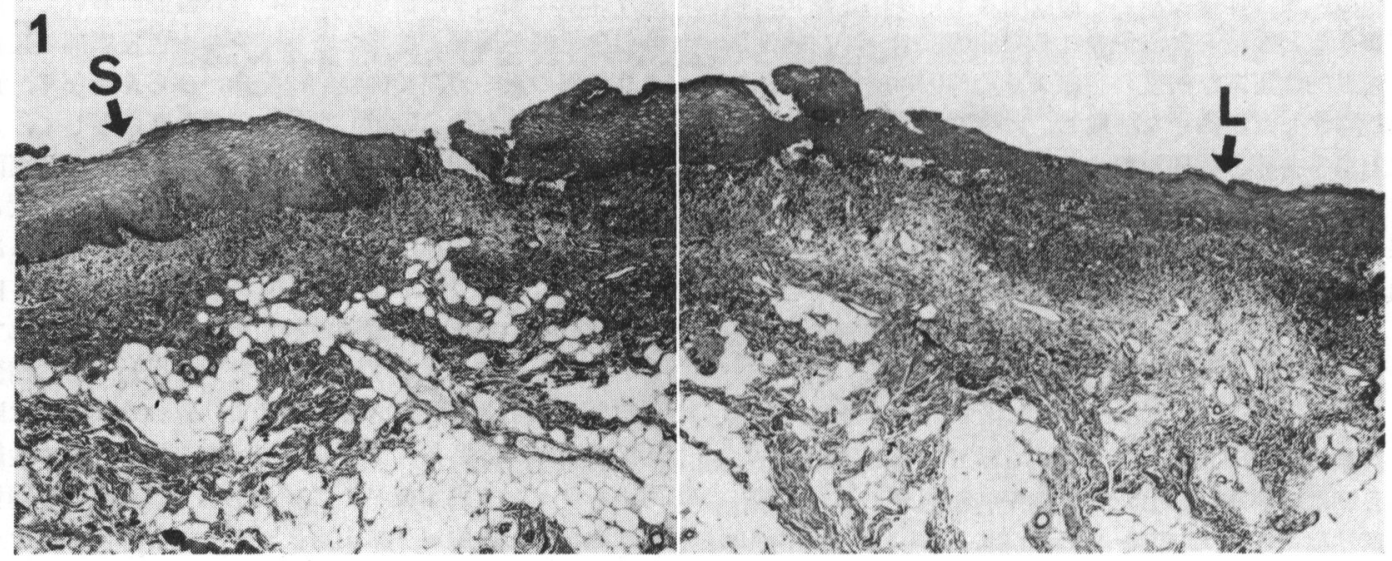

写真 1 口腔扁平苔廐の病変部と周辺部の病理組織像

矢印 $\mathrm{L}$ は病変部, $\mathrm{S}$ は病変部より約 $10 \mathrm{~mm}$ 離れた周辺部 $(\mathrm{H}-\mathrm{E}$ 染色, $\times 35)$

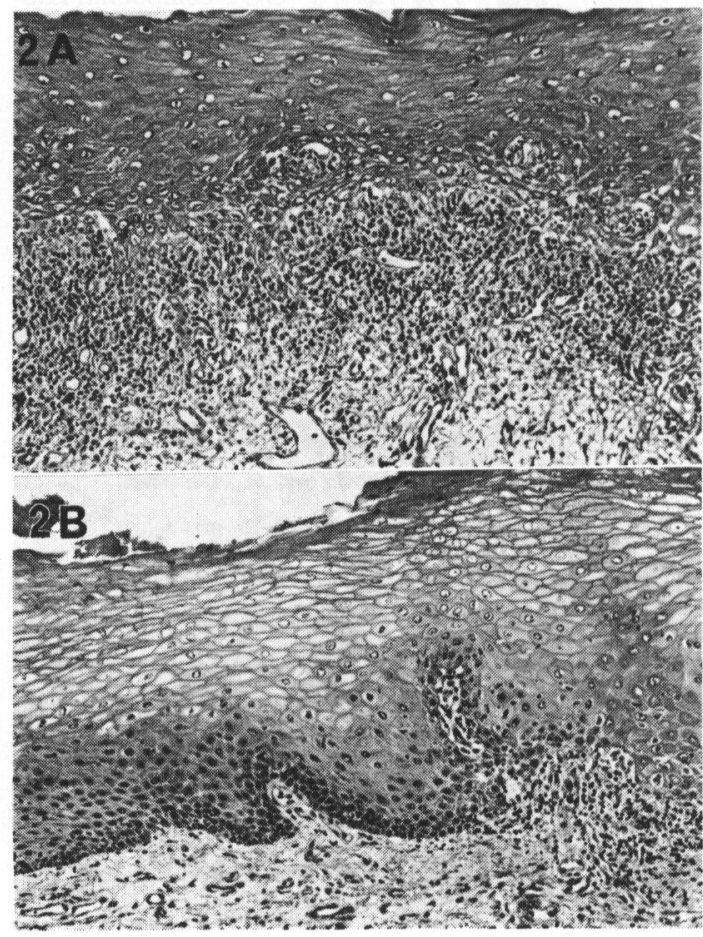

写真 2 口腔扁平苔痽の病変部と周辺部の病理組織像

$2 \mathrm{~A}$ : 写真 1 の病変部 $\mathrm{L}$ の拡大像

$2 \mathrm{~B}$ : 写真 1 の周辺部 $\mathrm{S}$ の拡大像

(H-E 染色, $\times 140)$

層の肥厚は病変部では 18 例中 2 例 $(11 \%)$, 周辺部には 生じなかった。 c) 棘細胞症の出現は病变部は18例中 4 例 $(22 \%)$, 周辺部では 18 例中 1 例（6\%）のみであっ た。ｄ）基底細胞層の障害は病变部では18例中16例（89 $\%$ ), 周辺部では18例中 8 例 $(44 \%)$ 飞認められた。 e )

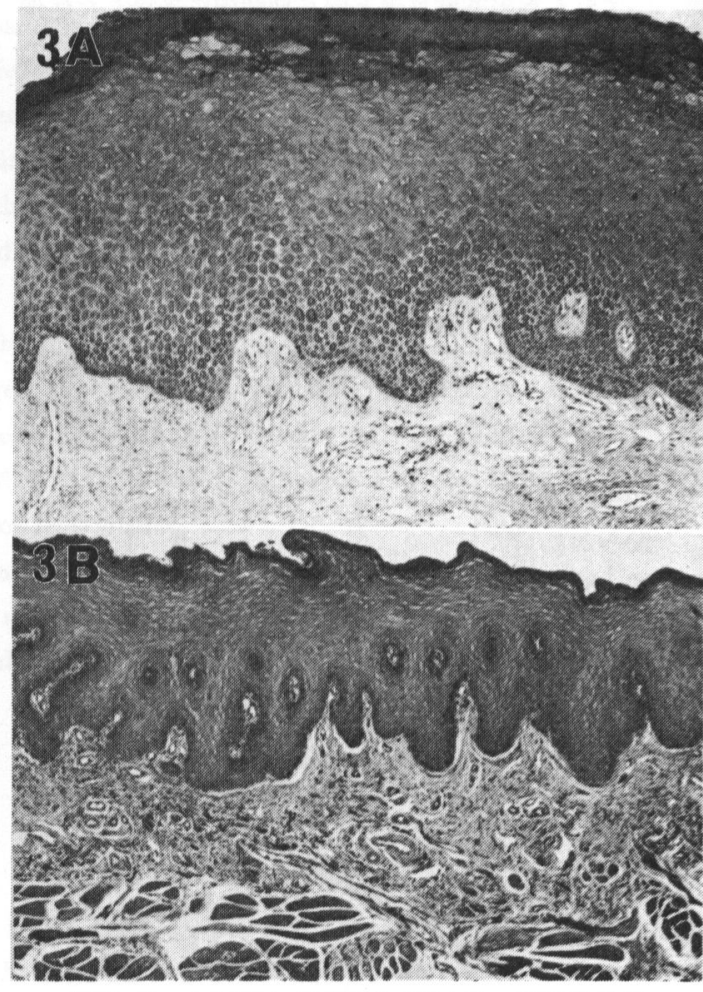

写真 3 白板症の病育部と周辺部の病理組織像

$$
\begin{aligned}
& 3 \mathrm{~A}: \text { : 病変部 } \\
& 3 \mathrm{~B}: \text { 周辺部 } \\
& \quad(\mathrm{H}-\mathrm{E} \text { 染色, } \times 56)
\end{aligned}
$$

上皮直下の帯状細胞浸潤の出現頻度は病変部では全例, 周辺部は18例中14例 $(78 \%$ ) 飞子及んた （写真 1，2）。 病理組織像の変化のうち, 主要所見であるa）角化立 進, d）基底細胞層の障害, e ）上皮直下帯状細胞浸潤 
表 3 扁平苔檫の角化䒕進, 基底紐胞層障害, 紐胞浸潤の出現頻度

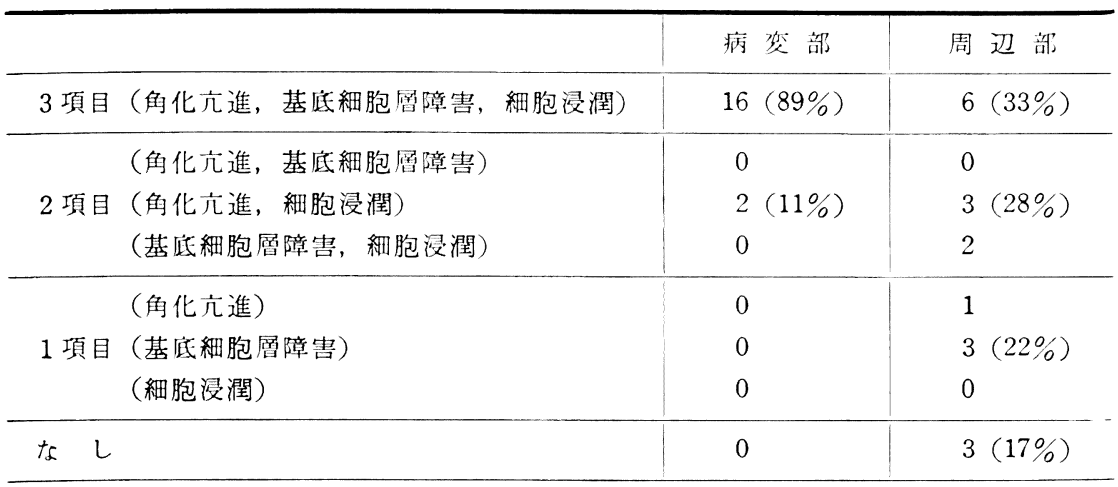

表 4 白板症の角化六進, 棘細胞症, 紐胞浸潤の出現頻度

\begin{tabular}{|c|c|c|c|}
\hline & & 病 変 部 & 周 辺部 \\
\hline 3 項目 & （角化元進，棘細胞症，細胞浸潤） & $8(62 \%)$ & $1(7 \%)$ \\
\hline \multirow{3}{*}{2 項目 } & （角化六進，棘細胞症） & 4 & 0 \\
\hline & （角化立進, 細胞浸潤） & $0(31 \%)$ & $2(15 \%)$ \\
\hline & （栜稩胞症，細胞浸潤） & 0 & 0 \\
\hline \multirow{3}{*}{1 項目 } & （角化元進） & 1 & 4 \\
\hline & （䗲細胞症） & $0(7 \%)$ & $0(39 \%)$ \\
\hline & （細胞浸潤） & 0 & 1 \\
\hline \multicolumn{2}{|l|}{ な し } & 0 & $5(39 \%)$ \\
\hline
\end{tabular}

の3項目がすべて発現した症例は，病変部では18例中16 例 (89\%) に対して周边部では6 例 (33\%)，2 項目は病 変部 2 例 $(11 \%)$, 周辺部 5 例 $(28 \%)$ であり, 周辺部で は1項目 4 例 $(22 \%)$, 変化のなかった症例は3 例（17 \%)で少なかった（表 3）.

上記の成績より, 周辺部に生じた上皮直下の带状細胞 浸潤は78\%に達し，角化充進，基底細胞層障害の発現頻 度も病変部よりやや低いとはいうものの，50\%前後に及 ぶこと，さらに周辺部では上記の 3 項目の変化のうち 11 例 $(61 \%)$ において，すでに3 項目ないし2 項目の变化 が確かめられた。

白板症群では，白板症の病理組織所見としてあげられ ている ${ }^{13,15,17)}$ a) 角化元進， b ) 棘紏胞症， C ) 細胞浸 潤の他に，基底細胞層障害について病変部之病変より約 $10 \mathrm{~mm}$ 離れた部位（周辺部）を比較した。

a) 角化六進は病変部では全例, 周辺部でも13例中 7 例 $(54 \%)$ に認められ，またb）棘紐胞症は病変部では13 例中12例 $(92 \%)$ に対して，周辺部はわずか 1 例( $8 \%$ )に とどまり，病変部と周辺部との差は著しかった。）細 胞浸潤は病変部13例中 8 例 $(62 \%)$, 周辺部 4 例 $(31 \%)$ であり，周辺部では少なかった（写真了）。なお，基底
細胞層の障害は扁平苔鮮と異なり，病変部に1例認めら れたのみであった。病変部，周辺部における角化六進， 棘細胞症, 細胞浸潤の 3 項目の発現状態を集計すると, 3 項目のそ万った症例は病变部 8 例 $(62 \%)$, 周辺部 1 例 $(7 \%), 2$ 項目注病変部 4 例 $(31 \%)$, 周辺部 2 例 (15\%) であり，1項目は病変部 1 例 $(7 \%)$, 周辺部 5 例 $(39 \%)$, 病変のない症例は周辺部のみ 5 例 $(39 \%)$ であ った（表 4 ).

上記の成績より周辺部では角化克進, 棘練胞症の発現 頻度はあきらかに病变部より少なく、細胞浸潤もまた周 辺部では少なく，2 項目以上の変化を示した症例は，病 変部では12例（93\%）を数えたのに対して周辺部ではわ ずか 3 例 $(22 \%)$ に過ぎなかった。

\section{2. 螢光抗体直接法の成績（表 5 ）}

Fibrinogen の沈着を扁平苔敦 16 例について調べた結 果, 病変部では16例中12例 $(75 \%)$, 周辺部で 16 例中 8 例 $(50 \%$ ) に基底膜を中心に带状に詉められた(写真 4). 補体成分の5ち C 3d の沈着は病变部, 周辺部之夕16例 中10例 $(63 \%), \mathrm{C} 3 \mathrm{c}$ は病变部6 例 $(38 \%)$, 周辺部 5 例 (31\%) に認められ，雨者の検出率に差異はなかった。 $\mathrm{IgA}, \mathrm{IgM}, \mathrm{C} 4, \mathrm{C} 5$ の沈着流変部, 周辺部之车活之ん 
表 5 營光抗体直接法の成績

\begin{tabular}{|c|c|c|c|c|c|c|c|c|c|c|}
\hline 病 & 名 & 例数 & $\operatorname{IgA}$ & IgG & $\operatorname{IgM}$ & $\mathrm{C} 3 \mathrm{c}$ & C3d & $\mathrm{C} 4$ & C5 & fibrinogen \\
\hline \multirow{2}{*}{ 扁平苔鹪 } & 病変部 & 16 & $1(6 \%)$ & $3(19 \%)$ & 0 & $6(38 \%)$ & $10(63 \%)$ & 0 & 0 & $12(75 \%)$ \\
\hline & 周辺部 & 16 & 0 & $4(25 \%)$ & 0 & $5(31 \%)$ & $10(63 \%)$ & $1(6 \%)$ & $3(19 \%)$ & $8(50 \%)$ \\
\hline \multirow{2}{*}{ 白 板 症 } & 病変部 & 8 & 0 & $1(13 \%)$ & $1(13 \%)$ & $2(25 \%)$ & $6(75 \%)$ & 0 & 0 & $2(25 \%)$ \\
\hline & 周辺部 & 8 & 0 & $1(13 \%)$ & 0 & $1(13 \%)$ & $3(38 \%)$ & 0 & 0 & $2(25 \%)$ \\
\hline
\end{tabular}

（）は検出率を示す

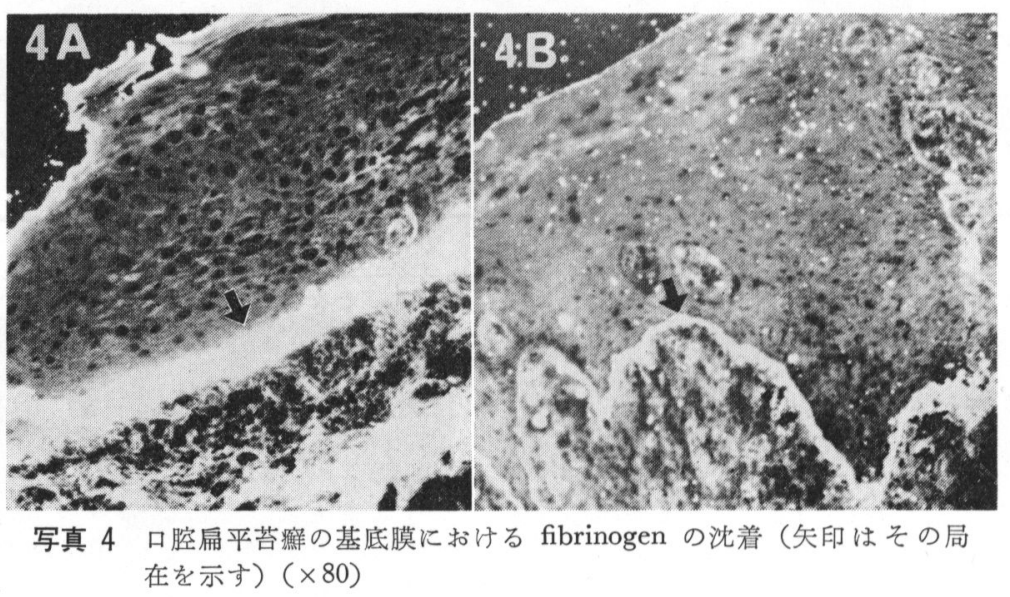

$4 \mathrm{~A}$ : 病卒部

$4 \mathrm{~B}$ ：周辺部

と゚なかった．以上，免疫グロブリンと補体成分の局在に 関しては病変部, 周辺部に洼とんどみられなかった。

一方, 白板症群では, 扁平苔癄飞叔いて病変部, 周辺 部とも基底膜を中心に高率に検出された fibrinogen の 沈着は病变部, 周辺部之も少なかった ( $25 \%$ ずつ). 補体 成分のうち C $3 \mathrm{~d}$ の沈着は病変部で 8 例中 6 例 $(75 \%)$, 周辺部で 8 例中 3 例 $(38 \%)$ に認められ, 両者の間には 差はあったが, IgA，IgG，IgM，C4，C5 の沈着は病変 部, 周辺部ともほとんど認められなかった。

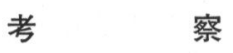

アトピー性皮膚炎では成人期に苔痽化した病変が広範 囲に拡がり, 病変部, 非病変部とも皮膚組織内 $\operatorname{IgE}$ 濃 度は正常人の皮膚よりも数倍, 特に病変部では顕著に高 く ${ }^{18)}$ ，また脂漏性皮膚炎非発疹部でも病巣部と同様に総 コレステロールは増加し, スクアレンや不飽和脂肪酸が 減少し, 表皮脂質の異常は病変の拡大波及に関係するこ とが知られている ${ }^{19}$. このように皮膚病変では病変周辺 の生化学的検討はなされているが，一般悪性病変を除 き皮覤や口腔粘膜病変では, 病变周辺の病理組織学的検
討はほとんど行われていない。

皮膚扁平苔癄と同一疾患である口腔扁平苔痽では, 扁 平紅色苔痽とも記されているように白色角化病変の周囲 にしばしば発赤を伴い経過中に病型は変ることがあるの で病巣の型による分類は意義がないという見解15)もあ る。攵の成り立ちに細胞性免疫機構の異常を示唆する所 見や10,12)，糖尿病 ${ }^{10)}$ ，女性ホルモン ${ }^{11)}$ の異常など全身的 因子の関与も報告されているので，前述の皮䖉病変ほど 著明ではないが, 口腔扁平苔痽でも病変の周辺になんら かの前段階の病変を示唆する所見が得られてもよいと推 定した。そのため, 病変部と病変の周辺より約 $10 \mathrm{~mm}$ 離れた部位を選び, 病理組織像と炟光抗体法により比較 検討する方法をとった。ささらに採取部位を䫅, 口唇に限 定した理由は，ともに組織学的に同じ構造を示し, 病型 もまた網状, 線状が多く, 組織像と病型に頓, 口唇部と 差がある舌, 歯肉, 口蓋粘膜は除外した方が成績の均一 化を計れると考穴たからである。白板症に执いても，切 片採取部位をすべて頓，口唇に限定した。

口腔扁平苔痽の病理組織像 ${ }^{13,15)}$ としてあげられてい る, a ) 角化六進, b ) 顆粒層の肥厚, c ）棘細胞症, d）基底細胞層の障害，e）上皮直下の帯状細胞浸潤の 
比較成績は，結果の項で示したように，a）角化え進は 病変部では18例中全例にみられ，周辺部ではこれよりも 少なかったが10例（56\%）に発現した。e）病変部で全 例生じた上皮直下の帯状細胞浸潤は周辺部でも14例(78 \%) の高率で確かめられ，さらにd）病変部で16例 (89 \%) に確認された基底細胞層障害もまた，周辺部では 8 例 $(44 \%)$ 㭘出できた。病理組織像の変化のうちこの 3 項目は主要所見であり, 病変より約 $10 \mathrm{~mm}$ 離れた一見 正常と思われる部位でも，2 項目以上の変化を示した症 例は11例 $(61 \%)$ に達し，かなりの症例ですでに病理組 織学的に扁平苔㒕を示唆する変化が先行していると考元 られた。な技，頓粘膜では周辺部は採りやすい前方を採 取した。頓粘膜では病変が後方より前方に桩大する傾向 のあることは指摘されており ${ }^{3}$ ，採取部位の影響も多少 関与すると思われる。

一方, 白板症の主要病理組織像 ${ }^{13,16,17)}$, a) 角化六進, b) 棘細胞症, c) 細胞浸潤は, 病変部で a) 13例中13 例 $(100 \%)$, b ) 12 例 (92\%)，c） 8 例 $(62 \%)$ に認 められたのに対して，周辺部ではa） 7 例 (54\%), b) 1 例 $(8 \%$ )，c） 4 例（31\%）であったので，頻度は 病変部よりはるかに低かった。そして, 角化元進, 棘細 胞症, 細胞浸潤の 3 項目のうち, 病変部では12例 (93\%) が3 項目ないし 2 項目の変化を示したのに対して, 周辺 部ではわずか 3 例 $(22 \%)$ に過ざず，周辺部では扁平苔 淮に比較して病理組織学的に白板症の発症を示唆する所 見は乏しかった。白板症は扁平苔率に比較して，その発 症の原因に局所的因子がより強く関与しているためと考 えられる。

口腔扁平苔铮では, 基底膜を中心に高頻度にfibrinogen が沈着することは Barthelmes ら ${ }^{20)}$ が報告して以来, 多 くの研究者 ${ }^{10,21,22)}$ により確かめられており, 口腔扁平苔 婙洔異的な所見として白板症, 全身性エリテマトーデ スの鑑別に役立つとのことである。自験例では病変部で 16例中12例（75\%）に基底膜を中心に fibrinogen が沈 着し，周辺部でも 8 例 $(50 \%)$ に検出できた。 てして， 白板症では病変部, 周辺部之も 8 例中 2 例に検出された にとどまり，fibrinogen の沈着は扁平苔察の方が有意に 多かった，補体成分もまた皮膚扁平苔僬では基底膜に沈 着するが23)，自験例では $\mathrm{C} 3 \mathrm{C}$ は病变部16例中 6 例 (38 $\%)$, 周辺部 5 例 $(31 \%), \mathrm{C} 3 \mathrm{~d}$ 法病变部, 周辺部之も 16 例中10例 $(63 \%)$ に検出され，病変部之周辺部之の差は なかった。一方，白板症では $\mathrm{C} 3 \mathrm{c}$ は病変部 8 例中 2 例 $(25 \%)$, 周辺部 1 例 $(13 \%)$ に見い出され，C3d は病 変部 8 例中 6 例 $(75 \%)$ に比較して，周辺部 3 例 $(38 \%)$ に沈着するにとどまった。このように螢光抗体直接法の 検討結果においてもまた，口腔扁平苔确では病変の周辺 で病変と類似の変化が起こりつつあり, 一方, 白板症で はこのような可能性は少ないと考えられる。

この場合, 周辺部をさらに離れた正常部と比較すべき
であるとの意見もあると思われる。しかし，本症例の多 くを占める40歳から60歳代の正常口腔粘膜では, 萎縮お よび角化穴進を生じるとの記述 $\left.{ }^{13}, 24\right)$ はあるが, 病理組織 学的に自験例で示されたほどの高頻度で角化六進, 細胞 浸潤, 基底細胞層障害, fibrinogen や補体成分の沈着を 起こすとは考えられない。

口腔扁平苔鷹においては臨床所見を最重視することは いらまでもないが, 病変より約 $10 \mathrm{~mm}$ 離れた肉眼的に は正常の部位に, すでにかなりの頻度で病理組織学的に 病変の発現を示呪するこの成績より, 本症の治療は白板 症亡同じ考光のもと行われている凍結療法を含む外科的 処置 ${ }^{25)}$ は㮃められない。ビタミンA酸䌘剂, 副腎皮質ホ ルモン剂, 柴胡剂や温清飲などの薬物の内服ないし病変

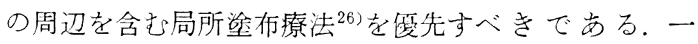
方, 白板症では, 扁平苔㢈と異なり病変は主に病巣に限

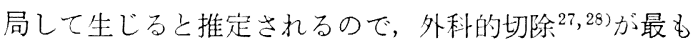
確実である。ただし，悪性化傾向が疑われる場合は周辺 を含めて切除すべきである。

\section{ま と め}

口腔扁平苔倠18例と白板症13例について, 病変部之病 变部辺縁より約 $10 \mathrm{~mm}$ 離れた肉眼的に正常の部位を採 取し, 病理組織学的括よび螢光抗体直接法を用いて検討 した。

1. 口腔扁平苔㶍の病変部では病理組織像の診断上重 要な 3 項目, 寸なわち角化穴進, 基底細胞層障害, 上皮 直下の帯状細胞浸潤は，てれぞれ100\%，89\%，100\%㤎 められたのに対して，周辺部でも56\%，44\%，78\%の高 率で検出された。そして, 周辺部でも 2 項目以上の病変 を生じた症例は11例（61\%）に達した。白板症では病理 組織診断の主要 3 項目, すなわち角化六進, 棘細胞症, 細胞浸潤の発現頻度は, 病変部に比較して周辺部では少 なく, かつ 2 項目以上の变化を示した症例はわずか 3 例 (22\%) に過ぎなかった。

2. 口腔扁平苔獤では病变部, 周辺部とも高頻度に fibrinogen は沈着し, $\mathrm{C} 3 \mathrm{c}, \mathrm{C} 3 \mathrm{~d}$ の局在もまた病变部, 周辺 部の間に差は少なかった。しかし，白板症では病変部， 周辺部に扁平苔寉汪どの類似性は見い出せなかった。

3. 以上の所見は, 口䅝扁平苔舞では白板症に比較し て病変の周辺に拈いても, 病理組織学的に扁平苔鮮を思 わせる变化が起こりつつあることを意味するので，口腔 扁平苔率では外科的処置よりも薬物療法を優先すべきで あると考えられる。一方，白板症では外科的処置が最も 確実である。

本論文の要旨は平成元年 10 月，第 34 回日本口腔外科学 会総会で報告した。病理学的所見についてご教示いたた いた第 1 病理学教室中里洋一教授に深爵する。 


\section{引用文 献}

1) Wilson, E.: On lichen planus. J Cutan Med 3: 117-132 1869.

2) Shklar, G. and McCarthy, P.L.: The oral lesions of lichen planus, observation on 100 cases. Oral Surg 14: 164-181 1961.

3) Herrmann, D: Lichen ruber planus der Mundschleimhaut, Untersuchungen über Klinik, Histologie und Therapie an 60 Fallen. DZZ 18: 346-363 1963.

4) Andreasen, J.O.: Oral lichen planus. I. A clinical evaluation of 115 cases. Oral Surg 25: 31-42 1968.

5) Andreasen, J.O.: Oral lichen planus. II. A histologic evaluation of ninety seven cases. Oral Surg 25: 158-166 1968.

6) McClatchey, K.D.: Studies on lichen planus. III. Clinical and histologic correlations in 231 patients. Oral Surg 39: 122-129 1975.

7) 村上 微：口腔粘膜病の検討。その 1 . 扁平紅 色苔锋について。科誌 15：22-27 1966.

8) 橋本和明: 口腔粘膜の扁平紅色苔鮮に関寸る研 究。口科誌 18：660-685 1969.

9) 池上邦男 : 口腔粘膜の扁平苔路に関する臨床的 ならびに病理学的研究. 口科誌 21：555-581 1972.

10）小池洋二：口腔扁平苔确の臨床ならびに病理学 的㭘討。北闺東医学 32：253-273 1982.

11) 丸茂町子：口腔粘膜扁平苔㩁の研究, 特に, 卵 胞ホルモン治療について。 日口外誌 23:97-120 1977.

12) 石井交行, 原田猛, 他：口腔扁平苔㪍の臨床 病理学的所見と免疫担当細胞の分布様相との関 連について。 日口外誌 36：50-55 1990.

13) 石川梧䬦, 秋吉正豊, 他: 口腔病理学 II. 永末 書店, 京都, 1982，44-47頁，215-219面.

14）武内章浩，芝 高志，他：チオプロニンによる 口腔粘膜の薬剂性扁平苔礔の症例。日口外誌 28: 478-482 1982.

15) McCarthy, P.L. and Shklar, G.: Diseases of the oral mucosa. 2nd Ed, Lea \& Febiger,
Philadelphia, 1980, p 188-191, 206-207.

16) WHO collaborating centre for oral precancerous lesions. Definition of leukoplakia and related lesions. An aid to studies on oral precancer. Oral Surg 46: 518-539 1978.

17) 横堀守：口腔白板症の臨床ならびに病理学的 検討. 北関東医学 40：37-61 1990.

18）上原正己，太藤重夫：現代皮酋科学大系.13巻, アトピー性皮覻炎。中山書店, 東京, 1980, 104105頁.

19）野原 望: 現代皮首科学大系, 13巻, 脂漏性皮 原炎。中山書店，東京，1980，129頁。

20) Barthelmes, H. and Haustein, U.F.: Nachweis von Fibrinablagerungen beim Lichen ruber planus mit Hilfe der Immnofluoreszenzhistologie. Derm Mschr 156: 86-96 1970.

21) Daniels, T.E. and Quadra-White, C.: Direct immunofluorescence in oral mucosal disease. A diagnostic analysis of 130 cases. Oral Surg 51: 38-47 1981.

22) Schidt, M., Holmstrupt, P., et al.: Deposits of immunoglobulins, complement, and fibrinogen in oral lupus erythematosus, lichen planus, and leukoplakia. Oral Surg 51:603-608 1981.

23) Abell, E., Persbury, D.G.C., et al.: The diagnostic significance of immunoglobulin and fibrin deposition in lichen planus. $\mathrm{Br} \mathrm{J}$ Dermatol 93: 17-24 1975.

24) 三宅浩郷：消化器官の加䊀変化. 老年医学 19: 641-646 1981.

25）中尾治郎，森 猛，他：Lichen planus に対吉 る Cryosurgery の臨床的研究. 日口外誌 25: 508-513 1979.

26）松田 登：扁平苔䇁に対する投薬はどのよ5に したらよいか、新・幽科に打けるくすりの使い 方。デンタルダイヤモンド社, 東京, 1987, 114-115面.

27）天笠光雄，戸塚盛雄，他：口腔白板症の臨床 型, 治療法と予後に関する研究。日口外誌 24 : 243-252 1978.

28）松田登，藤林孝司：口腔粘膜疾患の晾断と治 療。著林，東京，1983，48-51頁。 